\title{
Problems and Prospects of Repatriation
}

\author{
by Peter Rees
}

\section{The Great Return}

The largest number of refugees in recent history is waiting on the borders of Pakistan and Iran to return home. Over five million people wish to return to a country devastated by ten years of war.

Think, if you can, of being a displaced person; living outside your own country, under conditions that are far below those meagre conditions in which you lived before; bringing up your family in a situation of need and dependence. And the prospects of returning to your village? Your house and all its contents are destroyed, your fields have not been cultivated for ten years, your oxen to plough the land have vanished, the school in which your children studied is destroyed, your neighbours upon whom you depended face similar problems or are dead, all your savings in terms of cattle, livestock, jewelry, or cash are expended. And you now need to rebuild all these things, but you are destitute.

What would you do?

The agency I work for has spent the last five years trying to help those who wish to stay in Afghanistan. We see suffering and human degradation throughout the country: people surviving well past the stage of apparent impossibility. Often they must choose the unwanted option of becoming refugees.

Other countries have faced similar problems, though never in my experience on the scale of Afghanistan. In most other countries it has been possible to provide assistance packages for human survival, to assist people in their own villages. In Afghanistan this is not possible in most areas. Neither Afghan society nor Afghan geography facilitate the introduction of internal relief.

In many, probably most, parts of Afghanistan it is geographically, politically, ethnically, and logistically impossible to provide internal relief. Relief agencies, bilateral donors, and the UN face a prob-

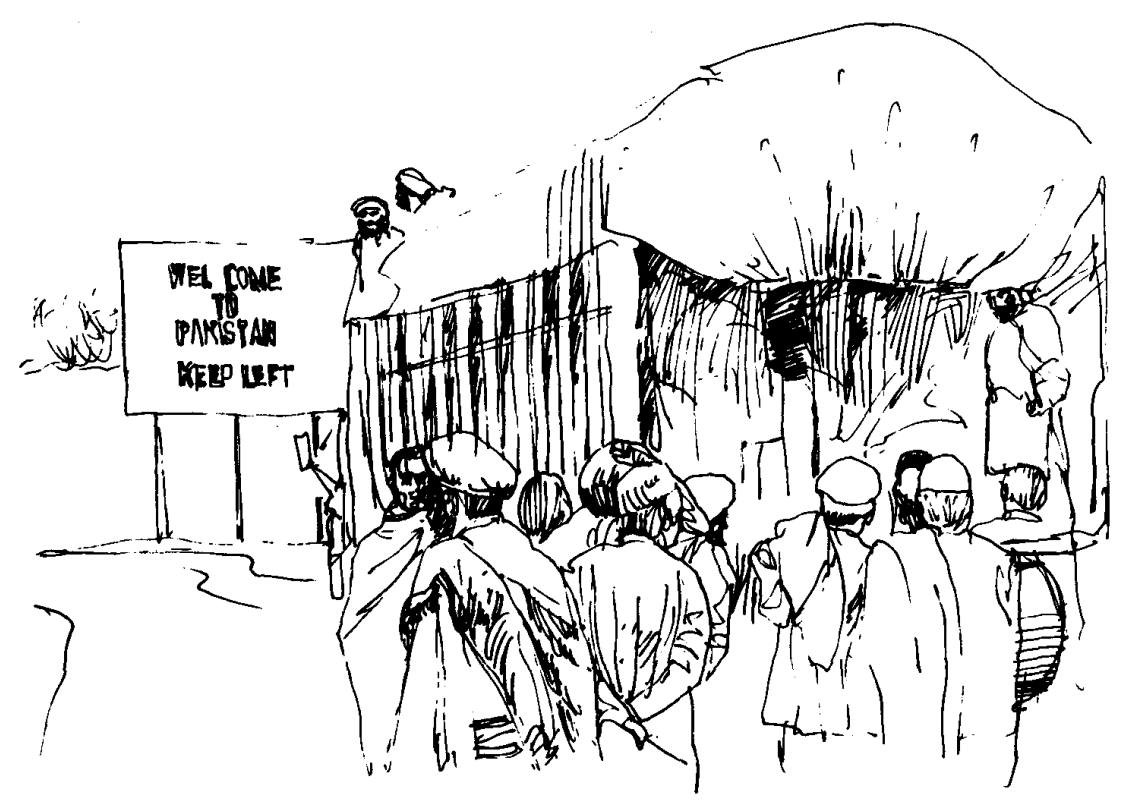

lem that has never been faced before. All the experience gained in other relief operations cannot apply to Afghanistan. We are all beginners facing the largest return of refugees ever witnessed in this century. In addition, we face land mines, the destruction of a whole country, destitution beyond comprehension - and five million refugees.

What can be done?

\section{Conceptual Policy}

While there can never be a single solution to the problems of Afghanistan, it is important to develop an overall strategy. Over the past year, especially since the signing of the Geneva Accords (April 14, 1988), a gradual evolution of a policy affecting refugee return has been developed between relief agencies, bilaterals, and the United Nations.
If it is understood that people cannot be assisted in their own country after return, the primary objective must be selfsufficiency upon return.

With such a large refugee community, it is important to look at the problems from a national or macro level. Food production in the country represents close equivalency to population. There have been some food imports into the country over the past ten years, most significantly from the Soviet Union, but generally food production supports the present population. The resident population cannot make up the food deficit for probably three years at best, needing a fifty percent increase in present production to feed those presently outside the country.

Therefore, if refugee return has to be self-reliant, and present food production is fifty percent below requirement, a satisfactory return must be based on an increase in national food production. 


\section{Areas of Increased}

\section{Food Production}

\section{Options exist:}

- Traditional areas of cultivation can be brought back into use.

- New areas of cultivation can be developed.

- Disease control can increase yields.

- Pest control can increase yields.

- Increased traction on farms can improve production levels.

- Fertilizers can improve yields.

- Improved seeds can improve yields.

But what do these options mean?

There are a host of problems that affect choices. Without facing these problems, some opportunities will not be so easy. To list an important few:

- It requires a stable government to introduce a development strategy that would have the resources and skill to bring barren land under cultivation.

- Pest and disease control are not traditional aspects of Afghan farming, at least not to the level required to dramatically affect yields. The use of fertilizer is a comparatively recent form of yield increase in many parts of Afghanistan.

- Mechanized traction is also historically limited to a few areas of Afghanistan.

- Irrigation systems have been reduced by approximately fifty percent over the last ten years due to war damage and lack of maintenance, and, at the same time, antipersonnel mines have been sluiced into these irrigation canals by rain, hampering rehabilitation work.

- Many of the traditional mirabs, those responsible for the distribution of water supplies, are refugees.

- The planting seed used at present by farmers has suffered by genetic degeneration over the past ten years, and most new seed has had insufficient testing time to be distributed in a wholesale manner until in-country tests have provided longer term results.

- Many roads essential for the distribution of the required agricultural inputs either have never existed, or have been damaged and require essential repairs.

- Returning refugees, despite proving highly resilient, may need assistance between planting and harvesting of crops.
And above and beyond all this, the war continues across the country. Indeed, this is the most essential point. While the resident population is still very much at war, and the increased food production for returnees has to come from them before a refugee return is possible, there can be little hope for a quick return of this vast refugee community.

Despite this gloomy picture, much is already being done to prepare Afghanistan for at least a limited return of refugees. In 1988 approximately US \$25 million went into Afghanistan for relief projects through voluntary agencies. More and more of this assistance is used for irrigation repair and food production programmes. In late $1988 \mathrm{UNHCR}$, under the auspices of the UN Coordinator's Office (Prince Sadruddin Agha Khan), some US $\$ 3.5$ million were provided to experienced relief agencies for projects to increase food production.

Feelings and attitudes throughout Afghanistan have become more and more positive towards rehabilitation, especially since the withdrawal of Soviet troops, due to the realization that the war might end. There have been new allegiances formed to create new village or district councils to co-ordinate relief operations. When all seemed so difficult, the Afghan approach to problems has begun to overcome apparently insurmountable problems once again.

To date there has been very little return of the refugee population; indeed those who have returned have often been forced to leave again because of Afghan government shelling or aerial bombings. There have been some signs, however, that this food production strategy will prove realistic and effective.

In one area near Kandahar, southeastern Afghanistan, for instance, a small group approached our agency asking for assistance to repair the irrigation system leading to their villages. A group of six villages from their area had been abandoned for many years, the whole population having been forced to leave for exile in Pakistan mainly because $\mathbf{3 5}$ kilometres of irrigation channels providing water to their areas had been destroyed.

A group of fifteen families were provided tents, as nearly all the houses in the area had also been destroyed. A daily wage was set (less than three dollars per day) so that this group could start repairs. With the assistance of some of our engineers, they fully repaired the irrigation system in a surprisingly short time and began planting their first crops. As the irrigation system was extended, it became possible to cultivate more and more land, and a steady trickle of refugees started to return. These new arrivals needed no assistance, no rations, no cash, nothing. Now that they had their land back, and food production was possible, they could survive. They will, however, receive some assistance during this year with seed, oxen, and fertilizer, to ensure that the maximum benefit is made of this land.

In other areas plans or actions are under way to repair irrigation, roads, bridges, houses, school, and mosques. Often just the smallest input from the agency is needed to start a whole series of reconstruction activities. The relief agencies are taking the position of catalysts; it is up to the Afghans themselves to organize the work. The Afghan problem needs Afghan solutions; relief agencies must follow this principal. Indeed, if they do not, it is unlikely the Afghans would tolerate them for very long.

These examples may paint too simplistic and rosy a picture of the solutions for Afghanistan. Relief agencies will expand greatly this year, with an increase in interest and, therefore, funding. However, even if all the agencies are put together and it would be assumed that all their programmes would be successful (which is virtually impossible), assistance would still reach less than fifteen percent of the population.

What is to be done for the remainder? There has been much debate over the past months, and as yet no positive consensus has been reached. The most likely solution may be to provide assistance through the private sector. Such a scheme has been called "project marketplace".

\section{Project Marketplace}

This war has damaged almost every aspect of the country, but not the private trading sector. Apart from paying local taxes at mujahidin check posts, the traders have been allowed by both sides to carry on business pretty much as usual. This provides important contacts with parts of the country where traditional relief efforts would not have access.

In a situation such as Afghanistan's, this presents an unusual opportunity, both to relief agencies and especially to UN agencies, many of which have mandates making such an approach difficult to come to terms with. Nevertheless, the UN Co- 


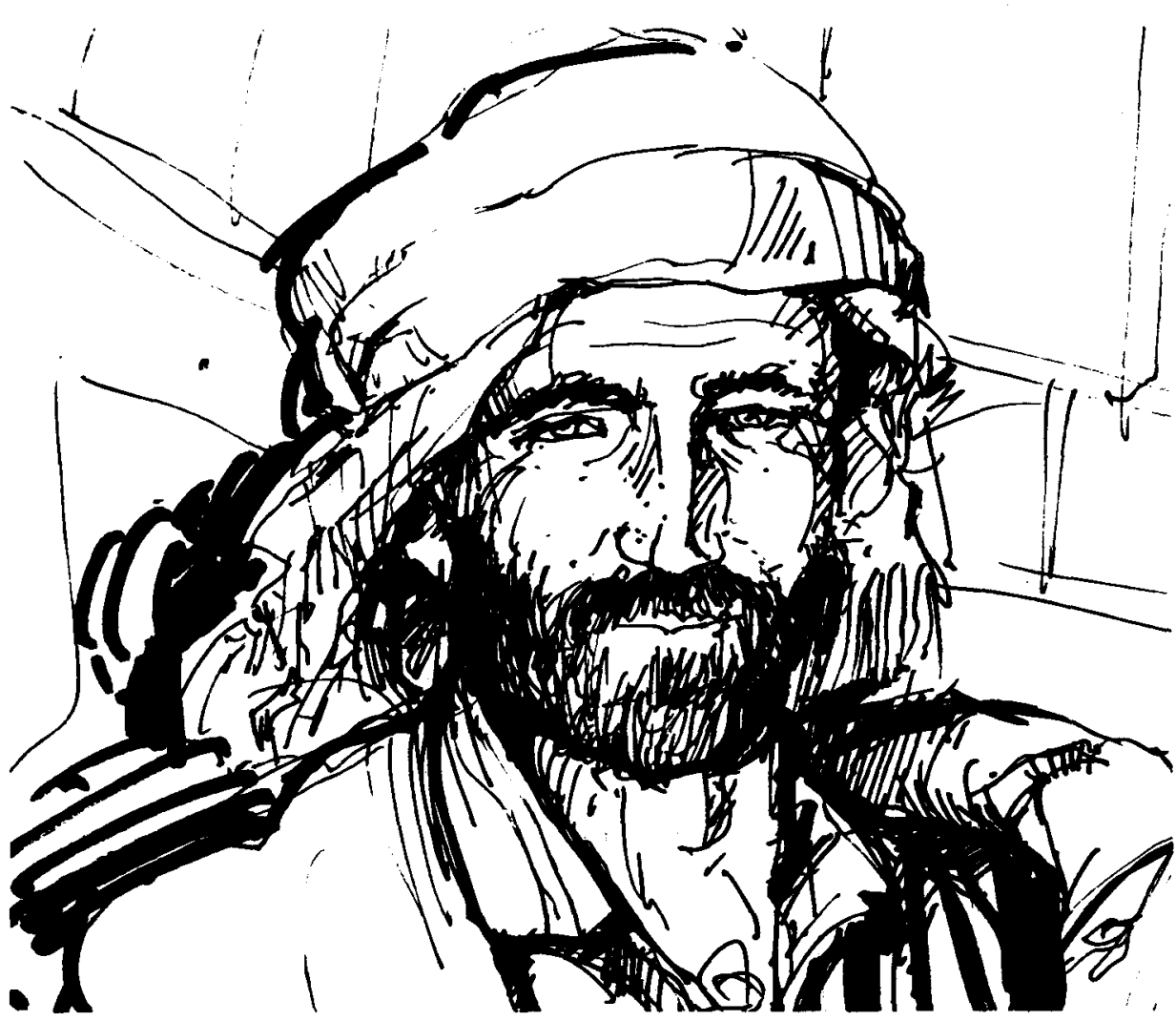

ordinator's Commission requires them to look for flexible solutions to difficult problems, thus permitting them to consider the evolution of the "project marketplace" concept.

Basically, the idea is to encourage the private sector, at subsidized rates, to deliver required commodities to those in need, financed through either the sale of ration cards or cash for work projects.

One might ask why the profit motive is not working effectively anyway, but alternative opportunities and the risks of war have excluded some essential parts of the market from commodity supply. Thus, agricultural wheat threshers are being sold for high profits in northern Afghanistan, but no food supplies are reaching rural areas around Kabul due to military and political problems.

In some form or another, the private sector will certainly play an essential role in the future economy of Afghanistan and thereby assist refugee return.

There are potential problems, nonetheless. Although the importance of the private sector is well understood, almost all present fuel to feed the delivery system comes into Afghanistan from the Soviet Union. Without fuel Afghanistan cannot survive, but this fuel comes from their present-day enemy, a difficult dilemma on both sides. and improved seed, as are threshers, tractors, and agricultural machinery, all vital to food production. Also crucial over the next few years will be food supplies of all sorts; cement, rebar, and building materials; oxen, livestock, poultry supplies, animal feed, horses, mules - the list is endless. These items not only need to reach pre-war requirements, but they are going to have to far exceed any previous imports to meet present and future reconstruction needs. The entrepreneurial skills of the Afghans may resolve some of the shortfalls, but the warning, on a national level, is all too apparent.

\section{Summary}

The scale of the refugee problem in Afghanistan is unprecedented. With incountry, direct primary assistance impossible in many parts of the country, food production is the major objective for the present. Food production, or a return of refugees in large numbers, is unlikely until there is a political or military solution to the continuing war. While much is being done already, especially by private voluntary agencies, the scope of the problem will require effective solutions from the private sector.

The potential for a worsening situation inside Afghanistan cannot be ruled out, especially if city sieges become military policy and fuel supplies become limited.

To balance this we can rely on the extraordinary resilience and adaptability of the Afghan people.

Interest in Afghanistan is sure to decline, especially with the withdrawal of the Soviet troops. With the decline in interest will come a decline in funding, unfortunately just at the time funding will be imperative. With so much to accomplish after so much has already been achieved, let us hope the opportunity for a peaceful and satisfactory resettlement will not be abandoned or restricted while so many wait for help.

Peter Rees, the Field Director of Afghanaid, has resided in Pakistan since July 1987. This is his tenth year of work with refugees, having previously worked for Laos and Khmer refugees in Thailand for The International Rescue Committee, Save The Children Fund (US), and The Ockenden Venture. He worked for The Ockenden Venture in the UK for four years, being responsible for Vietnamese resettlement and reception programmes. 